\title{
A NEW MEASURE FOR THAI STUDENTS' VOCABULARY SIZE: THE ENGLISH-THAI VERSION OF VOCABULARY SIZE TEST
}

\author{
SUPIKA NIRATTISAI \\ Phuket Rajabhat University \\ supika_mew@hotmail.com \\ Thanyapa Palanukulwong \\ Prince of Songkla University \\ thanyapa.c@psu.ac.th
}

\begin{abstract}
The main objective was to explore the reliability and validity of the bilingual English-Thai version of the vocabulary size test adapted based on Nation and Beglar (2007). The findings indicate that (1) the test is reliable; it produced consistent and stable results, (2) the test is valid; it well measures subjects' vocabulary size, (3) the words in each level are quite organized; the scores generally decline from the beginning level which is the easiest one $\left(1^{\text {st }} 1000\right.$ word level) to the highest level which is the most difficult one ( $14^{\text {th }} 1000$ word level), and (4) the test result shows that only 14 word levels are not sufficient to access the subjects' total vocabulary size; the test should contain more word levels. In all, the bilingual English-Thai version of the vocabulary size test is a reliable and valid measure of Thai students' vocabulary size.
\end{abstract}

Keywords: Bilingual, vocabulary, vocabulary size test, reliability, validity, Thai students. 


\title{
UNA NUEVA MEDIDA DEL TAMAÑO DEL VOCABULARIO DE LOS ESTUDIANTES TAILANDESES: LA VERSIÓN INGLÉS-TAILANDÉS DEL VOCABULARY SIZE TEST
}

\begin{abstract}
RESUMEN. El principal objetivo es explorar la fiabilidad y validez de la versión bilingüe del vocabulary size test adaptado, basado en Nation y Beglar (2007). Los resultados muestran que (1) el test es fiable, ya que los resultados obtenidos son consistentes y estables, (2) el test es válido, puesto que mide adecuadamente el tamaño del vocabulario, (3) las palabras en cada nivel están convenientemente organizadas; según indican los resultados del test, las puntuaciones disminuyen a partir del nivel principiante, que es el más elemental ( $1^{\circ}$ en el nivel de 1.000 palabras), hasta el último nivel, el más complejo ( $14^{\circ}$ en el nivel de 1.000 palabras), y (4) los catorce niveles de palabras de lo que consta el test resultan no ser suficientes para la evaluación del tamaño total del vocabulario de los estudiantes; el test, por tanto, debería contener más niveles de palabras. En definitiva, la versión bilingüe inglés-tailandés del vocabulary size test es una herramienta fiable y válida para medir el tamaño del vocabulario de los estudiantes tailandeses.

Palabras clave: Bilingüe, vocabulario, vocabulary size test, fiabilidad, validez, estudiantes tailandeses.
\end{abstract}

Received 28 April 2016

Revised version accepted 11 July 2016

\section{INTRODUCTION}

Vocabulary is an essential aspect of effective language use (Knight, 1994; Laufer, 1986; Schmitt, 2000). Many researchers, for instance, Laufer (1998) and Nation and Meara (2002), found high relationships between language skills and vocabulary knowledge. It means that the lack of learners' vocabulary knowledge would negatively affect their abilities in using the language: reading, listening, writing, and speaking skills. Thus, knowing learners' vocabulary size can be beneficial to all concerned parties, such as teachers and learners.

What are the main advantages of knowing learners' vocabulary size? First, vocabulary size helps teachers decide whether learners have adequate vocabulary for efficient language use or not. As mentioned above, vocabulary is an important factor of language, so it is necessary for learners to acquire enough word size; poor lexical knowledge tends to cause learners' poor language skills. According to Hirsh and Nation (1992) and Hu and Nation (2000), learners need to know $98 \%$ of running words in the text for sufficient comprehension, which is about 60007000 word families for spoken text and 8000-9000 word families for written text 
(Nation 2006). Second, knowing learners' word knowledge can help teachers develop language lessons. In order to design good lessons, it is very important for teachers to know learners' language proficiency, including vocabulary proficiency. If data on learners' word size is available, it will be easy for teachers to decide what word levels should be added in the lesson to improve their lexical repertoire and what texts, written or spoken, should fit their vocabulary level. Finally, learners' vocabulary size allows teachers to see learners' progress in vocabulary skill. Learners' word knowledge should largely grow over time.

Many tests for estimating learners' vocabulary knowledge have been proposed by researchers in this field, such as Nation (1983, 1990), Meara and Buxton (1987), and Nation and Beglar (2007). Among those well-known tests, the monolingual English version of the vocabulary size test developed by Nation and Beglar (2007) is one of the well-accepted tests.

The purpose of the monolingual English version of the vocabulary size test developed by Nation and Beglar (2007) is to measure learners' receptive vocabulary size which is a learner's ability to know word meanings while reading and listening. The test is a multiple choice format consisting of fourteen frequency word levels; each word level contains 10 items; the total is 140 items. The words in each frequency word level were chosen based on a frequency count of word families occurring in the British National Corpus (BNC). Each of the items begins with a target word followed by a simple sentence containing the word; a sentence shown in the item doesn't provide any clues for guessing the word meaning. For individual items, there are 4 options, there is only one correct choice which has the closest meaning to the target word and the other three are distractors. Here is the example of Item 10 from the $5^{\text {th }} 1000$ word level.

10. Bacterium: They didn't find a single bacterium.
a. small living thing causing disease
b. plant with red or orange flowers
c. animal that carries water on its back
d. thing that has been stolen and sold to a shop

As shown above, alternatives of each item of the original test are written in English language. The language used in some choices contains complicated grammar or difficult vocabulary. It means that, in order to answer some items of the test correctly, learners need to have quite a high knowledge of grammar and vocabulary. According to the example of item 10 from $5^{\text {th }} 1000$ word level shown above, the language small living thing causing disease used in option a consists of the reduced clause. The full sentence is "small living thing which 
causes disease". Moreover, the word "disease" is not an easy word for learners either; it may appear to be an unknown word for them. Therefore, the barriers, not understanding the grammar and language used in the options result in test takers not being able to come up with correct answer due to grammar and lexical complexity.

To avoid these problems, the options in the monolingual English version of the vocabulary size test developed by Nation and Beglar (2007) have been translated into the native language of the test takers, Thai language, which is the native language of Thai people.

There is evidence showing that the original test has a high quality for measuring learners' lexical size (Beglar 2010; Gyllstad 2012). There are no such studies conducted to establish the reliability and validity of the adapted version of the test. Therefore, this present study aimed to investigate the reliability and validity of the revised version of vocabulary size test.

The bilingual English-Thai version of the vocabulary size test used in this present research is an adapted version of the original version designed by Nation and Beglar (2007). This test version keeps all aspects of the original monolingual version excluding the language in the choices. The translation was approved by 2 experienced translation specialists. In addition, the extra option "I don't know" was added as the fifth alternative of each item. This added option would prevent learners from guessing; the guessing can distort the real lexical size of them. The example of Item 10 from the $5^{\text {th }} 1000$ word level is shown below.

10. Bacterium: They didn't find a single bacterium.
a. สิงมีชีวิตขนาดเล็กซึงทำให้เกิดโรค
b. พืชซึงมีดอกสีแดงหรือสีส้ม
c. สัตว์ซึงบรรจุน้ำไว้บนหลัง
d. สิงทีถูกขโมยและนำไปขายต่อให้ร้านค้า
e. ไม่ทราบคำตอบ

\section{RESEARCH QUESTIONS}

1. Does the bilingual English-Thai version of vocabulary size test perform consistently and stably?

2. Does the vocabulary size test well measure learners' vocabulary size?

3. Do the difficulties of words in the test decline from the high frequency word level to the lower one? 
4. Are the 14 word levels in the vocabulary size test enough to assess learners' total word size?

\section{SUBJECTS}

The subjects were 331 third-year university students studying in 6 different fields: medicine, dentistry, accounting, hospitality and tourism, engineering, and nursing at Prince of Songkla University, Hatyai and Phuket Campuses, Thailand.

\section{RESEARCH INSTRUMENT}

The bilingual English-Thai version of the vocabulary size test is the main instrument used in the present research. It is an adapted version of the monolingual version of the receptive vocabulary size test developed by Nation and Beglar (2007). The original version of vocabulary test is a multiple-option format. There are 14 word levels in total; each level consists of 10 words; the total amount of items of the test is 140 . The organization of individual words in the test is based on word difficulties, a highest frequency of word families revealed in the British National Corpus is arranged in the first word level of the test and the lower frequency of word family is arranged in the last word level. Each item begins with a target word followed by a non-defining phrase or sentence with the goal word.

The revised version of the receptive vocabulary size test keeps all features from the original test except for the language used in each alternative; they were translated from English to Thai. The language translated was checked for correctness and appropriateness by 2 translation specialists. In addition, an extra fifth choice was added in the test in order to prevent learners from guessing. Here is the comparison between the monolingual English version test and the bilingual English-Thai version test of Item 10 from the $5^{\text {th }} 1000$ word level.

\section{The original monolingual version}

10. Bacterium: They didn't find a single bacterium.
a. small living thing causing disease
b. plant with red or orange flowers
c. animal that carries water on its back
d. thing that has been stolen and sold to a shop
e.

\section{The adapted bilingual version}

10. Bacterium: They didn't find a single

\section{bacterium}
a. สีงมีชีวิตขนาดเล็กซึงทำให้เกิดโรค
b. พืชซึงมีดอกสีแดงหรือสีส้ม
C. สัตว์ซึงบรรจุน้าไว้บนหลัง
d. สีงทีถูกขโมยและนำไปขายต่อให้ร้านค้า
e. ไม่ทราบคำตอบ 


\section{DATA COLLECTION}

The researcher informed 331 participants of this study about the purpose of the study and test instruction. Then, the bilingual English-Thai version of the vocabulary size test was administered to all participants. Subjects had no time limit for completing the test, because we want to assess their vocabulary size, not test their speed.

\section{DATA ANALYSIS}

\subsection{MEASURING THE VOCABULARY SIZE}

In terms of the scoring of the vocabulary size test, a correct answer gets 1 point; an incorrect receives zero. To explore the subjects' vocabulary size, the total score from all 14 word levels is multiplied by 100. For instance, a learner who gets score of 55 out of 140 will have a vocabulary size of 5,500 word families.

\subsection{STATISTICAL ANALYSIS}

Cronbach's alpha was applied to indicate the consistency and stability of the test. Pearson's correlation coefficient was used to analyze the value of the relationship between language proficiency and vocabulary knowledge. Moreover, descriptive statistics were used to find the scores of each word level.

\section{RESULTS AND DISCUSSION}

Research question 1: Does the bilingual English-Thai version of the vocabulary size test perform consistently and stably?

To analyze the reliability, consistency and stability of the bilingual English-Thai version of the vocabulary size test, Cronbach's alpha was used. The data used to analyze the reliability was collected from 331 subjects. The interpretation of the reliability level of the test is based on Hatcher (1994). The Chonbach's alpha of above .70 is the acceptable value (Hatcher 1994).

According to Table 1, the reliability of the vocabulary size test, a total of 14 1000 word levels, is found to be high above the acceptable level $(a=.903)$. When the data of each word level was interpreted, the value of individual word levels is also reviewed at the above the acceptable value. The Chonbach's alpha of each word level ranged from .881 to .892 ; the $5^{\text {th }} 1000$ word level has the lowest value and the $1^{\text {st }} 1000$ word level has the highest value. 
It indicates that the bilingual English-Thai version of the vocabulary size test is reliable to measure the learners' vocabulary size. It produces consistent and stable results.

Table 1. Reliability of the vocabulary size test.

\begin{tabular}{ccc}
\hline \multirow{2}{*}{ Wbrd Level } & \multicolumn{2}{c}{ Reliability } \\
\cline { 2 - 3 } & Cronbach's Alpha & Interpretation of reliability \\
\hline $1^{\text {st }} 1000$ & .892 & acceptable \\
\hline $2^{\text {nd }} 1000$ & .883 & acceptable \\
\hline $3^{\text {rd }} 1000$ & .884 & acceptable \\
\hline $4^{\text {th }} 1000$ & .888 & acceptable \\
\hline $5^{\text {th }} 1000$ & .881 & acceptable \\
\hline $6^{\text {th }} 1000$ & .883 & acceptable \\
\hline $7^{\text {th }} 1000$ & .889 & acceptable \\
\hline $8^{\text {th }} 1000$ & .882 & acceptable \\
\hline $9^{\text {th }} 1000$ & .890 & acceptable \\
\hline $10^{\text {th }} 1000$ & .890 & acceptable \\
\hline $11^{\text {th }} 1000$ & .888 & acceptable \\
\hline $12^{\text {th }} 1000$ & .886 & acceptable \\
\hline $13^{\text {th }} 1000$ & .889 & acceptable \\
\hline $14^{\text {th }} 1000$ & .887 & acceptable \\
\hline$T^{\text {Total }}$ & .903 & acceptable \\
\hline
\end{tabular}

Research question 2: Does the test well measure learner's vocabulary size?

It has been admitted by many researchers (e.g. Laufer 1986; Hermann 2003) that vocabulary is a crucial element in language. To be able to read, listen, write, and speak effectively, word knowledge would be a key factor. Thus, the level of learners' English proficiency would correlate with their level of vocabulary knowledge. In other words, high English proficiency learners receive high scores from the vocabulary size test and low proficiency learners have low scores from the test. In order to see how well the test measures learners' vocabulary size, the correlation between learners' vocabulary size and proficiency is used.

It should be noted that the bilingual English-Thai version of the vocabulary size test under investigation is a test of receptive vocabulary size. Receptive vocabulary is related to receptive skills, reading and listening (Nation 1990; 
Schmitt 2010). In order to be sure that the bilingual English-Thai version of the vocabulary size test is a valid test, this present study aims to explore the relationship between the subjects' receptive vocabulary size and their receptive skills, their abilities to recognize word meanings while reading and listening. Therefore, the data of 331 subjects' English proficiency in both reading and listening skill, was collected 2 weeks before the administration of the bilingual English-Thai version of the vocabulary size test. The subjects' reading and listening skills are taken from the PSU English Tests, officially used and administered annually to all third-year students at Prince of Songkla University.

As shown in Table 2, the correlation between the subjects' English receptive knowledge and their lexical size is significant at a high level $(r=.806, p<.01)$. Moreover, the subjects' reading and listening scores are also significantly correlated with their vocabulary knowledge at a high level $(r=.785$ and .687$)$, respectively.

Based on these results, the high relationship between the subjects' reading and listening proficiency and their vocabulary size indicates that subjects with higher English proficiency would have higher vocabulary size, and subjects with lower English knowledge would have lower word knowledge.

As mentioned earlier, vocabulary knowledge plays an important factor in reflecting learners' receptive proficiency. As the correlation analysis pointed out above, it has been proven that this vocabulary size test can reliably assess subjects' word knowledge.

In conclusion, this bilingual English-Thai version of vocabulary size test performs well in measuring subjects' receptive vocabulary size.

Table 2. Relationship between vocabulary size and English proficiency.

\begin{tabular}{ccc}
\hline \multirow{2}{*}{ Receptive Skills } & \multicolumn{2}{c}{ Correlation between Vocabulary Size and English Receptive Skills } \\
\cline { 2 - 3 } & $\mathbf{r}$ & Level of correlation \\
\hline Reading & $.785^{* *}$ & high \\
\hline Listening & $.687^{* *}$ & high \\
\hline Reading \& Listening & $.806^{* *}$ & high \\
\hline
\end{tabular}

* Significant at the .01 level

Research question 3: Do the difficulties of words in the test decline from the high frequency word level to the lower one? 
In terms of the arrangement of words in the test, the difficulties of words must be related to the word levels of the test; the $1^{\text {st }} 1000$ word level, which is the first word level among 14 levels, should contain the words with the lowest difficulty in all levels, and the $14^{\text {th }} 1000$ word level, which is the last word level of all, consists of the words with the highest difficulty. That is, learners tend to know the high frequency words more than the low frequency words; they are likely to comprehend the words in $1^{\text {st }} 1000$ level better than the ones in $2^{\text {nd }} 1000$ level; they know more words in $2^{\text {nd }} 1000$ level than the ones in $3^{\text {rd }} 1000$ level, and so on. Thus, if the words in each level are ordered appropriately regarding their difficulties, Thai subjects' scores should drop from the $1^{\text {st }} 1000$ word level to $14^{\text {th }}$ word level.

Table 3 and Figure 1 contain the data of the subjects' vocabulary size for each of the 14 word levels. Although the results reveal that the decline of the subjects' word scores is not perfectly consistent, the tendency of their scores generally falls from the $1^{\text {st }} 1000$ level to the $14^{\text {th }} 1000$ level. The highest vocabulary score of the subjects is on the $1^{\text {st }}$ word level and the lowest score is on the $13^{\text {th }}$ word level. The mean scores from the $1^{\text {st }} 1000$ word level to $5^{\text {th }} 1000$ level properly decrease - subjects acquire the word sizes of $846,647,612,558,436$ for the $1^{\text {st }}, 2^{\text {nd }}, 3^{\text {rd }}, 4^{\text {th }}$, and $5^{\text {th }}$ word level, respectively. The subjects' score for the $8^{\text {th }}$ word level is in the sixth place (402), followed by the scores in $6^{\text {th }} 1000$ word level (353), $7^{\text {th }}(357), 11^{\text {th }}$ $(350), 12^{\text {th }}(307), 14^{\text {th }}(250), 9^{\text {th }}(246), 10^{\text {th }}(216), 13^{\text {th }}$ levels $(217)$, respectively.

Table 3. Descriptive Statistics of the test.

\begin{tabular}{ccccccc}
\hline \multirow{2}{*}{ Wbrd Level } & \multirow{N}{*}{$\mathbf{N}$} & \multicolumn{2}{c}{ Subjects' vocabulary size (word families) } & \multirow{2}{*}{ Rank } \\
\cline { 2 - 6 } & & Mean & SD & Minimum & Maximum & \\
\hline $1^{\text {st }} 1000$ & 331 & 846 & 133 & 300 & 1000 & 1 \\
\hline $2^{\text {nd }} 1000$ & 331 & 647 & 172 & 200 & 1000 & 2 \\
\hline $3^{\text {rd }} 1000$ & 331 & 612 & 159 & 100 & 1000 & 3 \\
\hline $4^{\text {th }} 1000$ & 331 & 558 & 136 & 200 & 900 & 4 \\
\hline $5^{\text {th }} 1000$ & 331 & 436 & 193 & 0 & 900 & 5 \\
\hline $6^{\text {th }} 1000$ & 331 & 353 & 169 & 0 & 800 & 7 \\
\hline $7^{\text {th }} 1000$ & 331 & 357 & 151 & 0 & 800 & 8 \\
\hline $8^{\text {th }} 1000$ & 331 & 402 & 214 & 0 & 1000 & 6 \\
\hline $9^{\text {th }} 1000$ & 331 & 246 & 170 & 0 & 800 & 12 \\
\hline $10^{\text {th }} 1000$ & 331 & 216 & 160 & 0 & 700 & 13 \\
\hline $11^{\text {th }} 1000$ & 331 & 350 & 147 & 0 & 800 & 9 \\
\hline $12^{\text {th }} 1000$ & 331 & 307 & 171 & 0 & 800 & 10 \\
\hline $13^{\text {th }} 1000$ & 331 & 217 & 136 & 0 & 700 & 14 \\
\hline $14^{\text {th }} 1000$ & 331 & 250 & 156 & 0 & 800 & 11 \\
\hline Ovverall $^{n}$ & 331 & 5798 & 14183 & 1900 & 11200 & \\
\hline
\end{tabular}




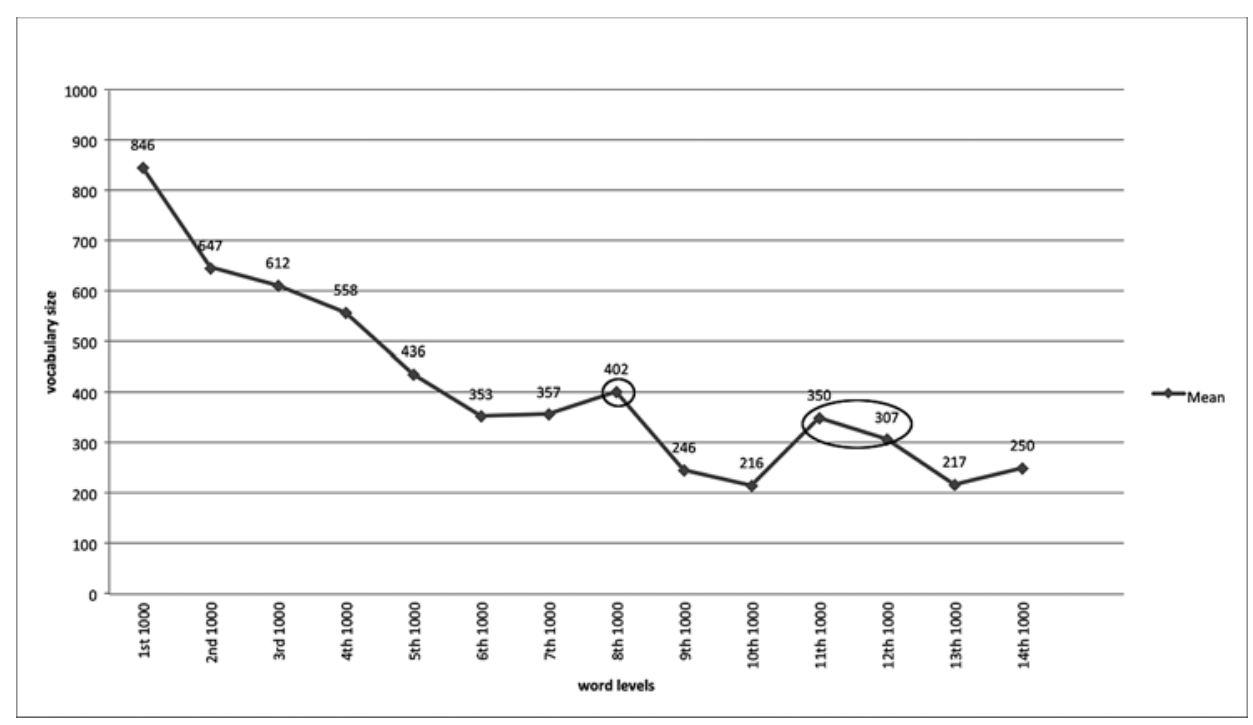

Figure 1. Vocabulary size in each word level.

The inconsistency appearing on the latter levels of the test may have occurred because of a number of reasons. First, learners might have guessed the meanings of unknown words, especially the words belonging to the high word levels. Even though an extra choice of "I don't know" is offered for each item, learners didn't tend to choose this option; they preferred to choose other alternatives instead. As a result, they might gain in score from their guessing.

Second, some words in the high level are very common in Thai context; some words have already become Thai words. Here is an example of common words in $7^{\text {th }}-14^{\text {th }}$ levels.

$7^{\text {th }}$ word level: olive, yoghurt

$9^{\text {th }}$ word level: octopus

$11^{\text {th }}$ word level: puma

$13^{\text {th }}$ word level: -

\author{
$8^{\text {th }}$ word level: kindergarten, cabaret \\ $10^{\text {th }}$ word level: - \\ $12^{\text {th }}$ word level: reptile, caffeine \\ $14^{\text {th }}$ word level: -
}

The high scores appearing abnormally on the $8^{\text {th }}, 11^{\text {th }}$, and $12^{\text {th }}$ levels may have been caused by those common words.

In total, the difficulties of words in the test tend to decrease from the high word level to the low word level. It means that the words in the test are quite 
organized. The low difficulty words are arranged in the low word levels and the high difficulty ones are arranged in the high word levels.

Research question 4: Are the 14 word levels in the vocabulary size test enough to assess learners' total word size?

As Table 4 shows, most subjects gain some scores in each word level of the test. There is only a small amount of them that receives zero score.

When the scores of the subjects in each word level are considered, the findings show that no learners have the score of zero in $1^{\text {st }}-4^{\text {th }}$ word levels. There are only 1.51 percent of learners having the score of zero in $5^{\text {th }}$ word level; 2.11 percent have zero score in $6^{\text {th }}$ word level; 1.21 percent have zero score in $7^{\text {th }}$ word level; 3.02 percent have zero score in $8^{\text {th }}$ word level; 12.99 percent have zero score in $9^{\text {th }}$ word level; 16.62 percent have zero score in $10^{\mathrm{h}}$ word level; 0.91 percent have zero score in $11^{\text {th }}$ word level; 6.95 percent have zero score in $12^{\text {th }}$ word level; 10.57 percent have zero score in $13^{\text {th }}$ word level; and 7.85 percent have zero score in $14^{\text {th }}$ word level.

According to the results, the subjects tend to receive some scores in the further word levels. It seems that the 14 word levels are not adequate to estimate subjects' total word size. Thus, to measure the subjects' real vocabulary size, it is necessary to have more word levels in the test.

Table 4. Scores in each word level.

\begin{tabular}{|c|c|c|c|c|c|c|c|c|c|c|c|}
\hline Wbrd & \multicolumn{10}{|c|}{ Number of students (\%) } \\
\cline { 2 - 13 } levels & Score0 & Scorel & Score2 & Score3 & Score4 & Score5 & Score6 & Score7 & Score8 & Score9 & Score10 \\
\hline 1000 & & & & 0.60 & 0.60 & 3.02 & 4.23 & 9.67 & 22.96 & 39.27 & 19.64 \\
\hline 2000 & & & 0.91 & 2.72 & 7.55 & 19.64 & 22.66 & 17.22 & 14.50 & 11.78 & 3.02 \\
\hline 3000 & & 0.30 & 0.91 & 2.42 & 12.39 & 19.64 & 23.56 & 19.03 & 16.01 & 4.83 & 0.91 \\
\hline 4000 & & & 0.91 & 4.83 & 15.11 & 27.49 & 26.89 & 17.22 & 5.74 & 1.81 & \\
\hline 5000 & $\mathbf{1 . 5 1}$ & 4.83 & 10.27 & 16.92 & 23.26 & 15.41 & 11.48 & 10.88 & 3.93 & 1.51 & \\
\hline 6000 & $\mathbf{2 . 1 1}$ & 10.27 & 16.31 & 22.36 & 19.34 & 16.31 & 9.67 & 2.72 & 0.91 & & \\
\hline 7000 & $\mathbf{1 . 2 1}$ & 5.44 & 16.92 & 29.00 & 20.85 & 16.62 & 6.95 & 1.81 & 1.21 & & \\
\hline 8000 & $\mathbf{3 . 0 2}$ & 9.37 & 13.90 & 18.73 & 13.29 & 15.71 & 13.90 & 5.74 & 4.23 & 1.51 & 0.60 \\
\hline 9000 & $\mathbf{1 2 . 9 9}$ & 14.20 & 27.49 & 22.05 & 13.60 & 6.34 & 2.42 & 0.30 & 0.30 & 0.30 & \\
\hline 10000 & $\mathbf{1 6 . 6 2}$ & 21.75 & 23.87 & 16.62 & 11.18 & 7.85 & 1.81 & 0.30 & & & \\
\hline 11000 & $\mathbf{0 . 9 1}$ & 6.95 & 16.92 & 26.89 & 24.77 & 16.31 & 3.63 & 3.02 & 0.60 & & \\
\hline 12000 & $\mathbf{6 . 9 5}$ & 12.39 & 18.43 & 24.17 & 15.71 & 14.20 & 6.65 & 0.91 & 0.60 & & \\
\hline 13000 & $\mathbf{1 0 . 5 7}$ & 24.47 & 25.98 & 20.54 & 13.90 & 4.23 & 0.30 & & & & \\
\hline 14000 & $\mathbf{7 . 8 5}$ & 21.45 & 23.56 & 24.17 & 12.99 & 5.14 & 3.63 & 0.91 & 0.30 & & \\
\hline
\end{tabular}




\section{CONCLUSION}

The research findings are summarized as follows:

1. The bilingual English-Thai version of vocabulary size test seems to be a reliable test to measure Thai learners' receptive vocabulary size. It has a consistency and repeatability of measuring learners' vocabulary size.

2. The bilingual English-Thai version of vocabulary size test is a valid test; the test well measures the subjects' vocabulary size. The findings reveal that there is a high relationship between subjects' English receptive skills and their vocabulary knowledge. In other words, the vocabulary size test can diagnose learners of different English proficiency; learners with high English proficiency receive a high English lexical size from the test and vice versa.

3. The words in the test are moderately organized; the words with the low difficulties appear in the low word levels and vice versa. The findings show that the subjects' vocabulary scores generally decrease from the $1^{\text {st }} 1000$ word level to the $14^{\text {th }} 1000$ word level. There were, however, some few words in the high word levels producing inconsistency due to learners' familiarity with the words in their Thai context.

4. It is necessary to have further word levels in the vocabulary size test. According to the findings, the subjects tend to have some scores on every word level: $1^{\text {st }}-14^{\text {th }}$ word levels, so they have a chance to receive more vocabulary scores on the higher word levels. Adding more word levels may positively affect learners' vocabulary size, some learners may gain more scores on the higher levels.

As mentioned above, it can be concluded that the bilingual English-Thai version of the vocabulary size test is reliable and valid to measure Thai learners' receptive vocabulary size. Moreover, the items in the test are found to be generally well organized. More word levels should be added in the vocabulary size test.

\section{FURTHER STUDIES}

The results showed that 14 word levels are insufficient for measuring learners' vocabulary size. For further investigation, research should be conducted to explore how many word levels should be added in the vocabulary size test.

\section{REFERENCES}

Beglar, D. 2010. "A Rash-based validation of the vocabulary size test". Language

Testing 27 (1): 101-118. 
Gyllstad, H. 2012. "Validating the vocabulary size test". $9^{\text {th }}$ annual EALTA conference. Hatcher, L 1994. A Step-by-Step Approach to using the SAS System for Factor Analysis and Structural Equation Modeling. Cary, NC: The SAS Institute.

Hermann, F. 2003. "Differential effects of reading and memorization of paired associates on vocabulary acquisition in adult learners of English as a second language". TESL-EJ: Teaching English as a second or foreign language 7 (1): 1-16.

Hirsh, D. and P. Nation. 1992. "What vocabulary size is needed to read unsimplified texts for pleasure?'. Reading in a Foreign Language 8 (2): 689-696.

$\mathrm{Hu}, \mathrm{M}$. and P. Nation. 2000. "Vocabulary density and reading comprehension". Reading in a Foreign Language 13 (1): 403-430.

Knight, S. 1994. "Dictionary use while reading: The effects on comprehension and vocabulary acquisition for students of different verbal abilities". Modern Language Journal 78 (3): 285-299.

Laufer, B. 1986. "Possible changes in attitude towards vocabulary acquisition research". IRAL 24 (1): 69-75.

Laufer, B. 1998. "The development of passive and active vocabulary in a second language: same or different?'. Applied Linguistics 19 (2): 255-271.

Meara, P. and B. Buxton. 1987. "An alternative to multiple choice vocabulary tests". Language Testing 4: 142-151

Nation, I.S.P. 1983. "Testing and teacher vocabulary". Guidelines 5: 12-25.

Nation, I.S.P. 1990. Teaching and learning vocabulary. Boston, MA: Heinle and Heinle.

Nation, I.S.P. and D. Beglar. 2007. "A vocabulary size test". The Language Teacher 31 (7).

Nation, P. and P. Meara. 2002. "Vocabulary". Ed. N. Schmitt. An introduction to applied linguistics. New York: Oxford University Press.

Schmitt, N. 2000. Vocabulary in language teaching. Cambridge: Cambridge University Press.

Schmitt, N. 2010. Researching vocabulary: A vocabulary research manual. Basingstoke: Palgrave Macmillan. 


\section{APPENDIX}

\section{The Bilingual English-Thai Version of Vocabulary Size Test}

Instruction: Choose the letter a-e with the closest meaning to the key word in the question.

\section{First 1000}

1 see: They saw it.
a. ตัด
b. รอ
c. ดู / มอง
d. เรีมต้น
e. ไม่ทราบคำตอบ

2 time: They have a lot of time.
a. เงืน
b. อาหาร
c. ชัวโมง
d. เพือน
e. ไม่ทราบคำตอบ

3 period: It was a difficult period.
a. คำถาม
b. ช่วงเวลา
c. สีงทีต้องทำ
d. หนังสือ
e. ไม่ทราบคำตอบ

4 figure: Is this the right figure?
a. คำตอบ
b. สถานที
C. เวลา
d. จำนวน
e. ไม่ทราบคำตอบ

5 poor: We are poor.
a. ไม่มีเงิน
b. รู้สึกมีความสุข
c. รู้สึกสนใจอย่างมาก
d.ไม่ชอบทำงานหนัก
e. ไม่ทราบคำตอบ

6 drive: He drives fast.
a. ว่ายน้า
b. เรียนรู้
C. ขว้างลูกบอล
d. ขับรถยนต์
e. ไม่ทราบคำตอบ

7 jump: She tried to jump.
a. ลอยตัวเหนือพืนน้า
b. พุ่งตัวจากพืนอย่างรวดเร็ว
C. หยุดรถยนต์ตรงขอบถนน
d. เคลือนทีอย่างเร็ว
e. ไม่ทราบคำตอบ

8 shoe: Where is your shoe?
a. ผู้ทีดูแลคุณ
b. สึงทีคุณใช้ใส่เงิน
c. สีงทีคุณใช้เขียน
d. สึงทีคุณสวมใส่ทีเท้า
e. ไม่ทราบคำตอบ

9 standard: Her standards are very high.
a. เศษของทีติดอยู่ใต้รองเท้าทางด้านหลัง
b. คะแนนสอบ
C. จำนวนเงินทีขอ
d. ระดับต่างๆทีได้รับหรือทำได้
e. ไม่ทราบคำตอบ

10 basis: This was used as the basis.
a. คำตอบ
b. สถานทีสำหรับพักผ่อน
c. ข้นตอนต่อไป
d. ส่วนประกอบหลัก
e. ไม่ทราบคำตอบ 


\section{Second 1000}

11 maintain: Can they maintain it?
a. รักษาไว้ในสภาพเดิม
b. ทำให้ใหญ่ขึน
C. เอาอันทีดีกว่าอันนี
d. ได้มา, ได้รับ
e. ไม่ทราบคำตอบ

12 stone: He sat on a stone.
a. สึงทีแข็ง
b. เก้าอีประเภทหนึง
C. วัสดุนุ่มบนพืน
d. ส่วนหนึงของต้นไม้
e. ไม่ทราบคำตอบ

13 upset: I am upset.
a. เหนือย
b. มีชือเสียง
C. รวย
d. ไม่มีความสุข
e. ไม่ทราบคำตอบ

14 drawer: The drawer was empty.
a. กล่องทีสามารถเลือนไป-มาได้
b. สถานที่ใช้จอดเก็บรถยนต์
C. ตู้ทีใช้สำหรับเก็บรักษาสึงของให้เย็น
d. ที่อยู่ของสัตว์
e. ไม่ทราบคำตอบ

15 patience: He has no patience.
a. รอคอยอย่างไม่มีความสุข
b. ไม่มีเวลาว่าง
C. ไม่มีความศรัทธา
d. ไม่รู้ว่าอะไรคือความยุติธรรม
e. ไม่ทราบคำตอบ

16 nil: His mark for that question was nil.
a. แย่มากๆ
b. ไม่มีอะไร
C. ดีมากๆ
d. กลางๆ
e. ไม่ทราบคำตอบ

17 pub: They went to the pub.
a. สถานทีทีผผู้คนดืมและพูดคุยกัน
b. สถานทีสำหรับเก็บรักษาเงิน
C. อาคารขนาดใหญ่ทีมีร้านค้ามากมาย
d. อาคารที่ใช้สำหรับการว่ายน้า
e. ไม่ทราบคำตอบ

18 circle: Make a circle.
a. ภาพร่างหยาบ ๆ
b. พืนที่าง
C. รูปร่างกลม
d. รูขนาดใหญ่
e. ไม่ทราบคำตอบ

19 microphone: Please use the microphone
a. เครืองสำหรับทำให้อาหารร้อน
b. เครืองที่ใช้เพืมความดังของเสียง
C. เครืองทีทำให้สีงของดูมีขนาดใหญ่ขึน
d. โทรศัพท์ขนาดเล็กสำหรับพกพา
e. ไม่ทราบคำตอบ

20 pro: He's a pro.
a. บุคคลผู้ถูกจ้างมาเพือสืบความลับสำคัญ
b. คนโง่เขลา
C. คนเขียนข่าวหรือบทความต่างๆในหนังสือพิมพ์
d. คนทีได้รับค่าตอบแทนจากการเล่นกีฬา
e. ไม่ทราบคำตอบ 


\section{Third 1000}

21 soldier: He is a soldier.
a. ผู้ทีทำงานในแวดวงธุรกิจ
b. นักเรียน, นักศึกษา
C. ผู้ใช้ใลหะ
d. ผู้ทีทำงานในกองทัพ, ทหาร
e. ไม่ทราบคำตอบ

22 restore: It has been restored.
a. พูดถึงอีกครัง
b. ให้กับอีกคนหนึง
C. ขายถูกกว่า/ให้ในราคาทีถูกกว่า
d. ทำให้เหมือนใหม่อีกครัง
e. ไม่ทราบคำตอบ

23 jug: He was holding a jug.
a. ภาชนะสำหรับเทของเหลว
b. การอภิปรายแบบไม่เบ็นทางการ
C. หมวกนีมๆ
d. อาวุธที่ใช้ระเบิด
e. ไม่ทราบคำตอบ

24 scrub: He is scrubbing it.
a. ทำให้เกิดร่องตืนๆ
b. ซ่อมแซม
C. ขัดถูอย่างแรงเพือทำความสะอาด
d. วาดภาพมันอย่างง่ายๆ
e. ไม่ทราบคำตอบ

25 dinosaur: The children were pretending to be dinosaurs.
a. โจรผู้ปล้นสะดมในทะเล
b. สีงมีชีวิตขนาดเล็กที่มีร่างกายเบ็นคนแต่มีปีก
C. สีงมีชีวิตขนาดใหญ่ ทีมีปีกและพ่นไฟ
d. สัตว์ซึงมีชีวิตอยู่เมือนานมาแล้ว
e. ไม่ทราบคำตอบ

26 strap: He broke the strap.
a. คำมันสัญญา
b. ฝาปิดด้านบน
C. จานก้นตืน ใช้ใส่อาหาร
d. วัสดุทีเบ็นเส้นยาว ใช้รัดสีงของเข้าด้วยกัน
e. ไม่ทราบคำตอบ

27 pave: It was paved.
a. ห้ามผ่าน
b. แบ่งออกเบ็นส่วนๆ
C. มีกรอบทองคำ
d. ปูด้วยวัสดุที่มีพืนผิวแข็ง
e. ไม่ทราบคำตอบ

28 dash: They dashed over it.
a. เคลือนที่อย่างรวด เร็ว
b. เคลือนทีอย่างช้าๆ
C. ต่อสู้
d. มองอย่างเร็ว
e. ไม่ทราบคำตอบ

29 rove: He couldn't stop roving.
a. เมาเหล้า
b. เคลือนไหวไป-มา
C. การผิวปาก
d. ทำงานหนัก
e. ไม่ทราบคำตอบ

30 lonesome: He felt lonesome.
a. ไม่สำนึกในบุญคุณ
b. เหนือยมาก
C. เหงา
d. เต็มไปด้วยพลัง
e. ไม่ทราบคำตอบ 


\section{Fourth 1000}

31 compound: They made a new compound.
a. การตกลง, ข้อตกลง
b. สีงทีประกอบด้วย 2 ส่วน หรือมากกว่า
C. กลุ่มคนที่วมทำธุรกิจ
d. การคาดเดาโดยอาศัยประสบการณ์ในอดีต
e. ไม่ทราบคำตอบ

32 latter: I agree with the latter.
a. ผู้ทีทำงานในโบสถ์หรือศาสนจักร
b. เหตุผลที่ให้
C. อันหลัง, อันสุดท้าย
d. คำตอบ
e. ไม่ทราบคำตอบ

33 candid: Please be candid.
a. ระมัดระวัง
b. แสดงความเห็นอกเห็นใจ
C. ให้ความยุติธรรมกับทังสองฝ่าย
d. พูดในสีงทีคุณคิดจริงๆ
e. ไม่ทราบคำตอบ

34 tummy: Look at my tummy.
a. ผ้าทีใช้คลุมศีรษะ
b. ท้อง
C. สัตว์มีขนขนาดเล็ก
d. น้วหัวแม่มือ
e. ไม่ทราบคำตอบ

35 quiz: We made a quiz.
a. สึงที่ใช้เก็บ/ใส่ลูกศร
b. ผิดพลาดร้ายแรง
C. ชุดคำถาม
d. กล่องสำหรับให้นกทำรัง
e. ไม่ทราบคำตอบ

36 input: We need more input.
a. ข้อมูล, พลังงาน และอืนๆ ที่ส่หรือป้อนเข้าไป
b. คนงาน
C. วัสดุประดิษฐ์ที่ใส่าเข้าไปเพืออุดช่องในเนือไม้
d. เงิน
e. ไม่ทราบคำตอบ

37 crab: Do you like crabs?
a. สัตว์ทะเลซึงเคลือนตัวไปทางด้านข้าง
b. เค้กชีนบางขนาดเล็ก
C. ปลอกคอแข็งตึงแน่น
d. แมลงสีดำตัวใหญ่ทีส่งเสียงร้องในเวลาคำคืน
e. ไม่ทราบคำตอบ

38 vocabulary: You will need more

\section{vocabulary.}
a. คำศัพท์
b. ทักษะ
C. เงิน
d. ปึน
e. ไม่ทราบคำตอบ

39 remedy: We found a good remedy.
a. วิธีการแก้ปัญหา
b. สถานทีรับประทานอาหารในทีสาธารณะ
C. วิธีการเตรียมอาหาร
d. กฎทีใช้สำหรับจำนวน, ตัวเลข
e. ไม่ทราบคำตอบ

40 allege: They alleged it.
a. อ้างความเบ็นเจ้าของโดยไม่ได้มีการพิสูจน์
b. ขโมยความคิดคนอืน
C. ให้ข้อเท็จจริงเพือพิสูจน์
d. โต้แย้งข้อเท็จจริงทีสนับสนุนมัน
e. ไม่ทราบคำตอบ 
Fifth 1000

41 deficit: The company had a large deficit
a. ใช้จ่ายมากกว่ารายรับอย่างมาก
b. ราคาลดลงอย่างมาก
C. มีแผนการใช้จ่ายทีต้องใช้เงินจำนวนมาก
d. มีเงินจำนวนมากในธนาคาร
e. ไม่ทราบคำตอบ

42 weep: He wept.
a. จบหลักสูตร
b. ร้องไห้
C. ตาย
d. กังวล
e. ไม่ทราบคำตอบ

43 nun: We saw a nun.
a. สึงมีชีวิตมีลักษณะผอมยาว ทีอาศัยอยู่ในดิน
b. อุบัติเหตุร้ายแรง
C. สตรีซึงปฏิบัติตามหลักศาสนาอย่างเคร่งครัด
d. แสงสว่างประหลาดที่เกิดขึนบนท้องฟ้า
e. ไม่ทราบคำตอบ

44 huant: The house is haunted.
a. เต็มไปด้วยเครืองตกแต่ง
b. มีคนเช่าแล้ว
C. ว่าง
d. เต็มไปด้วยผี
e. ไม่ทราบคำตอบ

45 compost: We need some compost.
a. การสนับสนุนช่วยเหลืออย่างเต็มที
b. ช่วยให้รู้สึกดีขึน
C. วัสดุแข็งทำขึนจากหินและดินทรายผสมกัน
d. สีงที่เกิดจากการเน่าเบือยของพืช
e. ไม่ทราบคำตอบ

46 cube: I need one more cube.
a. สึงของมีคม ใช้เชือมสึงของเข้าด้วยกัน
b. ก้อนของแข็งรูปสีเหลียม
C. ถ้วยลักษณะสูง ไม่มีจานรอง
d. กระดาษแข็งพับ ครึง
e. ไม่ทราบคำตอบ

47 miniature: It is a miniature.
a. สึงทีมีขนาดเล็กมากๆเมือเทียบกับของของ อย่างเดียวกับช้นอืนๆ
b. อุปกรณ์สำหรับดูสึงของขนาดเล็ก
C. สีงมีชีวิตขนาดเล็กมากๆ
d. เส้นขนาดเล็กที่เชือมต่อตัวอักษรที่เขียนเบ็นล ายมือ
e. ไม่ทราบคำตอบ

48 peel: Shall I peel it?
a. แช่ในน้ำไว้เป็นเวลานาน
b. ปอกเปลือกออก
C. ทำให้เบ็นสีขาว
d. ตัดเป็นชันบางๆ
e. ไม่ทราบคำตอบ

49 fracture: They found a fracture.
a. การแตก, รอยแตก
b. ช้นขนาดเล็ก
C. เสือคลุมส้นๆ
d. เพชรพลอยหายาก
e. ไม่ทราบคำตอบ

50 bacterium: They didn't find a single bacterium.
a. สึงมีชีวิตขนาดเล็กซึงทำให้เกิดโรค
b. พืชซึงมีดอกสีแดงหรือสีส้ม
C. สัตว์ซึงบรรทุกน้ำไว้บนหลัง
d. สีงทีถูกขโมยและนำไปขายต่อให้กับร้านค้า
e. ไม่ทราบคำตอบ 


\section{Sixth 1000}

51 devious: Your plans are devious.
a. มีเล่ห์เหลียม
b. ซึงพัฒนามาอย่างดี
C. ขาดการไตร่ตรอง
d. ราคาแพงเกินความจำเป็น
e. ไม่ทราบคำตอบ

52 premier: The premier spoke for an hour.
a. คนทีทำงานในศาล
b. อาจารย์ในมหาวิทยาลัย
C. นักผจญภัย
d. ผู้นำรัฐบาล
e. ไม่ทราบคำตอบ

53 butler: They have a butler.
a. คนใช้ผู้ชาย
b. เครืองตัดต้นไม้
C. ครูสอนส่วนตัว
d. ห้องมืดและเย็น ที่อยู่ช้นใต้ดินของบ้าน
e. ไม่ทราบคำตอบ

54 accessory: They gave us some accessories.
a. เอกสารอนุญาตให้เข้าประเทศ
b. คำสังทางราชการ
C. ความคิดเห็นสำหรับให้เลือกใช้
d. ชีนทีได้เกินมา
e. ไม่ทราบคำตอบ

55 threshold: They raised the threshold. 60
a. ธง
b. จุดหรือเส้นที่เกิดการเปลียน
C. หลังคาในตัวอาคาร
d. ค่าธรรมเนียม ในการยืมเงิน
e. ไม่ทราบคำตอบ

56 thesis: She has completed her thesis.
a. รายงานการศึกษาขนาดเพือใช้ประกอบการรับปริ ญญา
b. คำแถลงของผู้พิพากษาเมือจบการพิจารณาคดี
C. ปีแรกของการทำงานในฐานะอาจารย์
d. การขยายเวลาของการรักษา
e. ไม่ทราบคำตอบ

57 strangle: He strangled her.
a. ฆ่าเธอโดยการรัดคอ
b. ให้ทุกสีงทุกอย่างทีเธอต้องการ
C. เอาตัวเธอไปโดยการบังคับ
d. ชืนชมเธออย่างมาก
e. ไม่ทราบคำตอบ

58 cavalier: He treated her in a cavalier manner.
a. ไม่เอาใจใส่ หรือ ไม่ดูแล
b. อย่างสุภาพ
C. อย่างงุ่มง่าม
d. อย่างทีพีชายคนหนึงควรจะทำ
e. ไม่ทราบคำตอบ

59 malign: His malign influence is still felt.
a. ชัวร้าย
b. ดี
C. สำคัญมาก
d. เบ็นความลับ
e. ไม่ทราบคำตอบ

veer: The car veered.
a. เปลียนทิศทางอย่างฉับพลัน
b. เคลือนทีอย่างไม่มันคง
C. ทำเสียงดังมาก
d. ไถลออกด้านข้าง โดยทีล้อไม่ได้หมุนตาม
e. ไม่ทราบคำตอบ 


\section{Seventh 1000}

61 olive: We bought olives.
a. ผลไม้ซึงมีน้ำมัน
b. ดอกไม้สีชมพูหรือแดง มีกลีนหอม
C. ชุดว่ายน้าผู้ชาย
d. อุปกรณ์สำหรับขุดถอนวัชพืช
e. ไม่ทราบคำตอบ

62 quilt: They made a quilt.
a. ข้อความซึงระบุว่าผู้ใดควรได้รับทรัพย์สิน มือเจ้าของสมบัติเสียชีวิต
b. ข้อตกลงที่แน่นอน
C. ผ้าคลุมเตียงหนาและอบอุ่น
d. ปากกาทำจากขนนก
e. ไม่ทราบคำตอบ

63 stealth: They did it by stealth.
a. การใช้จ่ายเงินจำนวนมาก
b. ทำร้ายผู้อืนอย่างมากจนผู้น้นต้องยอมจำนน
C. เคลือนไหวลับๆ ด้วยความระมัดระวังและ ความเงียบอย่างมาก
d. ไม่สังเกตว่ามีปัญหา, ไม่รู้ว่ามีปัญหา
e. ไม่ทราบคำตอบ

64 shudder: The boy shuddered.
a. พูดด้วยเสียงเบาๆ
b. เกือบจะหกล้ม
C. สัน
d. เรียกเสียงดัง
e. ไม่ทราบคำตอบ

65 bristle: The bristles are too hard.
a. คำถาม
b. ขนที่มีลักษณะแข็งและส้น
C. เตียงแบบพับได้
d. พืนรองเท้า
e. ไม่ทราบคำตอบ

66 bloc: They have joined this bloc.
a. วงดนตรี
b. กลุ่มหัวขโมย
C. ทหารกลุ่มเล็กๆทีถูกส่งเพือ เบ็นทัพหน้า
d. กลุ่มประเทศซึงมีเป้าหมายเดียวกัน
e. ไม่ทราบคำตอบ

67 demography: This book is about demography.
a. การศึกษาเกียวกับรูป แบบการใช้พืนที
b. การศึกษาการใช้ภาพในการแสดงข้อเท็จจริงเกียว กับตัวเลข
C. การศึกษาเกียวกับการเคลือนทีของน้า
d. การศึกษาเกียวกับประชากร
e. ไม่ทราบคำตอบ

68 gimmick: That's a good gimmick.
a. สึงที่ใช้ยืนเพือทำงานในทีที่สูงจากพืนดิน
b. สีงของขนาดเล็ก ทีมีกระเป๋าสำหรับใส่เงิน
C. การกระทำหรือสีงที่ใช้เพือเรียกความสนใจ
d. แผนหรือกลยุทธ์ทีชาญ ฉลาด
e. ไม่ทราบคำตอบ

69 azalea: This azalea is very pretty.
a. ต้นไม้ขนาดเล็ก มีดอกเบ็นช่อ
b. วัสดุน้ำหนักเบาทำจากเส้นใยธรรมชาติ
C. ผ้าชันยาว ทีหญิงชาวอินเดียสวมใส่
d. หอยซึงมีรูปร่างคล้ายพัด
e. ไม่ทราบคำตอบ

70 yoghurt: This yoghurt is disgusting.
a. โคลนสีเทาซึงพบได้ทีกันแม่น้า
b. แผลเปิดทีดูไม่ดี
C. นมซึงข้นมีรสเปรียว ส่วนมากมีน้ำตาลและ การป รุงแต่งรสชาด
d. ผลไม้สีม่วงขนาดใหญ่ทีมีเนือนีม
e. ไม่ทราบคำตอบ 


\section{Eighth 1000}

71 erratic: He was erratic.
a. ไม่มีข้อบกพร่อง
b. แย่มาก
C. สุภาพมาก
d. ไม่มันคง เปลียนแปลงง่าย
e. ไม่ทราบคำตอบ

72 palette: He lost his palette.
a. ตะกร้าสำหรับใส่ปลา
b. ความอยากอาหาร
C. ผู้อยู่เบ็นเพือนทีเบ็นผู้หญิงสาว
d. จานผสมสีของศิลปิน
e. ไม่ทราบคำตอบ

73 null: His influence was null.
a. ได้ผลลัพธ์ทีดี
b. ไม่มีประโยชน์
C. ไม่มีผลใดๆ
d. ยาวนาน, ยืนยาว
e. ไม่ทราบคำตอบ

74 kindergarten: This is a good

\section{kindergarten.}
a. กิจกรรมทีทำให้คุณลืม ความกังวล
b. สถานทีเรียนรู้สำหรับเด็กทีอายุไม่ถึงเกณฑ์ เข้าโรงเรียน
C. กระเป๋าทรงสูงแข็งแรง ใช้สะพายหลัง
d. สถานทีทีคุณยืมหนังสือได้
e. ไม่ทราบคำตอบ

75 eclipse: There was an eclipse
a. ลมแรง
b. เสียงดังทีเกิดจากการทีบางสึงกระทบน้า
C. การฆ่าผู้คนจำนวนมาก
d. ดวงอาทิตย์ถูกดาวเคราะห์บัง
e. ไม่ทราบคำตอบ

76 marrow: This is the marrow.
a. สัญลักษณ์นำโซคข องที่ม
b. ส่วนนุ่มๆตรงกลางของกระดูก
C. เครือง/แผงควบ คุม เครืองบิน
d. การขึนเงินเดือน
e. ไม่ทราบคำตอบ

77 locust: There were hundreds of locusts
a. แมลงมีปีก
b. ผู้ช่วยซึงไม่ได้รับค่าตอบแทน
C. ผู้ทีไม่กินเนือสัตว์
d. ดอกไม้ป่า ที่สีสันสวยงามสดใส
e. ไม่ทราบคำตอบ

78 authentic: It is authentic.
a. จริง
b. เสียงดังมาก
C. แก่, เก่า
d. เสมือนทะเลทราย
e. ไม่ทราบคำตอบ

79 cabaret: We saw the cabaret.
a. ภาพวาดทีใหญ่ปิดผนังทังหมด
b. การแสดงการร้องเพลงและการเต้น
C. แมลงคลานขนาดเล็ก
d. คนที่มีลักษณะครึงปลา ครึงหญิงสาว
e. ไม่ทราบคำตอบ

80 mumble: He started to mumble.
a. คิดอย่างไตร่ตรอง
b. สันอย่างควบ คุมไม่อยู่
C. อยู่ล้าหลังผู้อืนอย่างมาก
d. พูดไม่ชัดถ้อยชัดคำ
e. ไม่ทราบคำตอบ 


\section{Ninth 1000}

81 hallmark: Does it have a hallmark?
a. การประทับตราเพือระบุเวลาการใช้งานของ สิงๆน้น
b. การประทับตราเพือแสดงถึงคุณภาพของสีงของ
c. เครืองหมายที่ใช้แสดงว่าสึงน้นได้รับการรับรองโ ดยราชวงศ์
d. เครืองหมายหรือร่องรอยทีลบออกไม่ได้ ใช้เพือ ป้องกันการเลียนแบบ
e. ไม่ทราบคำตอบ

82 puritan: He is a puritan.
a. ผู้ทีชอบให้ผู้อืนสนใจ
b. ผู้ทีเคร่งครัดในศีลธรรมจรรยา
c. ผู้ทีอาศัยอยู่ในบ้านทีสามารถเคลือนย้ายได้
d. บุคคล ผู้ไม่ชอบใช้จ่ายเงิน
e. ไม่ทราบคำตอบ

83 monologue: Now he has a

\section{monologue.}

a. เลนส์ตาเดียวใช้ส่องเพือให้เห็นชัดขึน

b. การพูดโดยคนคนเดียวเบ็นระยะเวลายาวนาน โดย ไม่มีการขัดจังหวะ

C. ตำแหน่งทีมีอำนาจเบ็ดเสร็จ

d. ภาพทีสร้างขึนโดยใช้ตัวอักษรต่อกัน ด้วยวิธีที่น่าสนใจ

e. ไม่ทราบคำตอบ

84 weir: We looked at the weir.
a. ผู้ทีมีพฤติกรรมแปลกๆ
b. พื้ที่เต็มไปด้วยโคลน, เปียกซืน และมีพืชน้าขึน
C. เครืองดนตรีทำจากโลหะโบราณ เล่นโดยการเป่า
d. สึงทีสร้างขวางแม่น้ำ เพือควบคุม
e. ไม่ทราบคำตอบ

85 whim: He had lots of whims.
a. เหรียญทองโบราณ
b. ม้าเพศเมีย
c. ความคิดทีแปลก โดยไม่มีสาเหตุหรือแรงจูงใจ
d. ก้อนเนือทีบวมแดงและเจ็บ
e. ไม่ทราบคำตอบ

86 perturb: I was perturbed.
a. ถูกบังคับให้ยอมรับหรือตกลงยินยอม
b. กลุ้มใจ, กังวลใจ
c. ประหลาดใจอย่างมาก
d. เปียกมาก
e. ไม่ทราบคำตอบ

87 regent: They chose a regent.
a. บุคคลซึงขาดความรับผิดชอบ
b. ผู้ดูแลการจัดการประชุมเบ็นครังๆไป
c. ผู้ผำเร็จราชการแทนพระมหากษัตริย์
d. บุคคลผู้เบ็นตัวแทนกลุ่ม
e. ไม่ทราบคำตอบ

88 octopus: They saw an octopus.
a. นกขนาดใหญ่ ทีหากินในเวลากลางคืน
b. เรือทีสามารถเคลือนตัวภายใต้ท้องน้ำได้
C. เครืองจักรซึงบินโดยการหมุนของใบพัด
d. สึงมีชีวิตใต้ท้องน้า ทีมี 8 ขา
e. ไม่ทราบคำตอบ

89 fen: The story is set in the fens.
a. พืนทีตำ ทีบางส่วนปกคลุมด้วยน้า
b. พืนทีสูง ทีมีต้นไม้ไม่มาก
c. กลุ่มบ้านคุณภาพตำในเขตเมือง
d. เมือนานมาแล้ว
e. ไม่ทราบคำตอบ

90 lintel: He painted the lintel.
a. คานซึงอยู่เหนือประตูหรือหน้าต่าง
b. เรือขนาดเล็กใช้สำหรับเดินทางจาก เรือใหญ่ขึนผัง
C. ต้นไม้สวยงาม ที่มีกึก้านสาขาและผลสี่เขียว
d. ฉากแสดงในโรงละคร
e. ไม่ทราบคำตอบ 


\section{Tenth 1000}

91 awe: They looked at the mountain with awe.
a. ความกังวล
b. ความสนใจ
C. ความแปลกใจ
d. ความเคารพ
e. ไม่ทราบคำตอบ

92 peasantry: He did a lot for the peasantry.
a. คนท้องถีน
b. สถานทีที่ใช้เคารพบูชา
C. สมาคมนักธุรกิจ
d. ชาวไร่ ชาวนาผู้มีรายได้น้อย
e. ไม่ทราบคำตอบ

93 egalitarian: This organization is

\section{egalitarian.}

a. ไม่เบิดเผยข้อมูลของบริษัทส่วนใหญ่ต่อ

$$
\text { สาธารณชน }
$$

b. ไม่ชอบการเปลียนแปลง

C. มักร้องขอให้ศาลช่วยตัดสินความ

d. ปฏิบัติต่อทุกคนในทีทำงานราวกับว่าเท่าเทียมกัน

e. ไม่ทราบคำตอบ

94 mystique: He has lost his mystique.
a. ร่างกายที่มีสุขภาพแข็งแรง
b. วิธีลึกลับซึงทำให้ผู้อืนเชือว่าบุคคลผู้น้นมีพ ลังวิเศษ
C. หญิงทีเบ็นคนรักของเขา ขณะทีเขามีภรรย าแล้ว
d. ขนหนวดเหนือริมฝีปากบน
e. ไม่ทราบคำตอบ

95 upbeat: I'm feeling really upbeat about it.
a. ไม่สบายใจ
b. รู้สึกดี
C. รู้สึกเจ็บปวด
d. รู้สึกสับสน
e. ไม่ทราบคำตอบ

96 cranny: We found it in the cranny!
a. การขายสินค้าทีไม่ต้องการแล้ว
b. ซอกเล็กซอกน้อย
c. ทีเก็บของใต้หลังคาบ้าน
d. กล่องไม้ขนาดใหญ่
e. ไม่ทราบคำตอบ

97 pigtail: Does she have a pigtail?
a. ทรงผมที่เกิดจากการถักเกลียวผมเข้าด้วยกัน
b. ผ้าจำนวนมากทีแขวนอยู่ด้านหลังเสือชุด
C. ต้นไม้ที่มีช่อดอกส้นสีชมพูอ่อน
d. คนรัก
e. ไม่ทราบคำตอบ

98 crowbar: He used a crowbar.
a. แท่งเหล็กที่มีน้ำหนักมากมีส่วนปลายโค้ง
b. ชือปลอม
C. เครืองมือสำหรับเจาะหนัง
d. ไม้เท้าทำจากโลหะน้ำหนักเบา
e. ไม่ทราบคำตอบ

99 ruck: He got hurt in the ruck.
a. ทีว่างระหว่างกระเพาะอาหารและโคนขา
b. การผลักและการดัน
C. กลุ่มผู้เล่นซึงรุมล้อมลูกบอล ในเกมส์ กีฬาที่เล่นโดยใช้ลูกบอล
d. การแข่งขันข้ามลานหิมะ
e. ไม่ทราบคำตอบ

100 lectern: He stood at the lectern.
a. แท่นวางหนังสือในระดับสำหรับการอ่าน
b. โต๊ะหรือแท่นใช้สำหรับการทำพิธีบูชาในโบสถ์
C. สถานทีสำหรับซือเครืองดืม
d. สุดขอบ, ริมสุด
e. ไม่ทราบคำตอบ 


\section{Eleventh 1000}

101 excreted: This was excreted recently.
a. ผลัก หรือ ส่งออก
b. ทำให้สะอาด, ชัดเจน
c. ถูกค้นพบด้วยวิธีทดลองทางวิทยาศาสตร์
d. รวบรวมรายชือสีงผิดกฎหมาย
e. ไม่ทราบคำตอบ

102 mussel: They bought mussels.
a. ลูกบอลแก้วขนาดเล็ก ใช้ในการเล่นเกมส์
b. สัตว์น้ำจำพวกที่มีเปลือก
C. ผลไม้สีม่วงขนาดใหญ่
d. กระดาษนุ่มใช้สำหรับป้องกันการเลอะระหว่าง รับประทานอาหาร
e. ไม่ทราบคำตอบ

103 yoga: She has started yoga.
a. งานฝีมือทำโดยการถักเส้นใย
b. การออกกำลังกายชนิดหนึง เพือพัฒนาร่าง กายและจิตใจ
C. เกมส์การเล่นโดยเดาะลูกขนไก่ระหว่างผู้เล่ นสองคน
d. การเต้นรำประเภทหนึง ที่มาจากประเทศท างตะวันออก
e. ไม่ทราบคำตอบ

104 counterclaim: They made a

\section{counterclaim.}
a. ข้อเรียกร้องของคู่ความฝ่ายหนึงให้สอดคล้องกับ ข้อเรียกร้องของอีกฝ่ายหนึง
b. การขอคืนสินค้าซึงมีตำหนิ
c. ข้อตกลงระหว่าง 2 บริษัทในการแลกเปลียนงาน
d. ผ้าคลุมเตียง
e. ไม่ทราบคำตอบ

105 puma: They saw a puma.
a. บ้านขนาดเล็ก สร้างจากอิฐซึงทำจากโคลน
b. ต้นไม้จากประเทศเขตร้อนและแล้ง
C. ลมทีมีพลังสูง ซึงดูดทุกสึงอย่างทีอยู่ในเส้น ทางทีมันผ่าน
d. แมวป่าขนาดใหญ่
e. ไม่ทราบคำตอบ

106 pallor: His pallor caused them concern.
a. อุณหภูมิร่างกายทีสูงกว่าปกติ
b. การขาดความสนใจในทุกสึงทุกอย่าง
c. กลุ่มเพือน
d. ความขาวซีดของผิวพรรณ
e. ไม่ทราบคำตอบ

107 aperitif: She had an aperitif.
a. เก้าอียาวสำหรับเอนนอน มีทีพักแขนหนึงด้าน
b. ครูสอนร้องเพลงส่วนตัว
c. หมวกขนาดใหญ่ ปักขนนกยาว
d. เครืองดืมซึงดืมก่อนมืออาหาร
e. ไม่ทราบคำตอบ

108 hutch: Please clean the hutch.
a. แท่นโลหะซึงใช้กันสีงสกปรกลงไปในท่อ
b. พืนทีท้ายรถยนต์สำหรับวางกระเป๋า
C. ซ้นส่วนโลหะ ตรงส่วนกลางของล้อจักรยาน
d. กรงสำหรับสัตว์ขนาดเล็ก
e. ไม่ทราบคำตอบ

109 emir: We saw the emir.
a. นกทีมีขนหางโค้งยาว
b. ผู้หญิงผู้ดูแลเด็กเล็กในประเทศทางตะวันออก
c. ผู้ครองนครในประเทศตะวันออกกลาง
d. บ้านทีสร้างจากก้อนน้าแข็ง
e. ไม่ทราบคำตอบ

110 hessian: She bought some hessian.
a. ปลาซึงมีน้ำมันมาก สีตัวค่อนข้างชมพู
b. วัตถุทีสร้างความสุขใจ
C. ผ้าเนือหยาบ
d. รากพืชรสชาดจัด ใช้ปรุงแต่งรสชาติอาหาร
e. ไม่ทราบคำตอบ 


\section{Twelfth 1000}

111 haze: We looked through the haze.
a. หน้าต่างรูปทรงกลม ขนาดเล็กบนเรือ
b. อากาศขมุกขมัว
C. แผ่นไม้หรือแผ่นพลาสติกยาว ใช้บังหน้าต่าง
d. บัญชีรายชือ
e. ไม่ทราบคำตอบ

112 spleen: His spleen was damaged.
a. กระดูกเข่า
b. อวัยวะอยู่ใกล้กระเพาะอาหาร
C. ท่อระบายน้ำเสียออกจากตัวบ้าน
d. นับถือตัวเอง
e. ไม่ทราบคำตอบ

113 soliloguy: That was an excellent

\section{soliloquy!}
a. เพลงสำหรับร้องโดย 6 คน
b. คำคมส้นๆ ทีมีความหมายลึกซึง
C. ความบันเทิง ที่ใช้แสงสีและเสียงดนตรีประกอบ
d. การพูดของนักแสดงทีแสดงคนเดียวฉากในโรงละคร
e. ไม่ทราบคำตอบ

114 reptile: She looked at the reptile.
a. หนังสือเขียนมือ ซึงมีอายุเก่าแก่
b. สัตว์เลือดเย็น มีผิวหนังแข็งหุ้มร่างกาย
C. ผู้ขายสินค้า ทีเคาะประตูตามบ้าน
d. รูปภาพ ทีทำขึนโดยการปะติดปะต่อช้นส่วน ขนาดเล็กๆซึงมีสีต่างๆเข้าด้วยกัน
e. ไม่ทราบคำตอบ

115 alum: This contains alum.
a. สึงมีพิษจากพืชทีพบได้ทัวไปชนิดหนึง
b. วัสดุนุ่ม ทำขึนจากเส้นใยสังเคราะห์
C. ผงยาเส้นทีเมือก่อนใช้สำหรับอุดเข้าไปในจมูก
d. สสารประกอบทางเคมีในกลุ่มอลูมิเนียม
e. ไม่ทราบคำตอบ

116 refectory: We met in the refectory.
a. ห้องรับประทานอาหาร
b. สำนักงานสำหรับการลงนามในเอกสาร ทางกฎ หมาย
C. ห้องนอนรวม
d. เรือนกระจกสำหรับปลูกพืช
e. ไม่ทราบคำตอบ

117 caffeine: This contains a lot of caffeine.
a. สารซึงทำให้มีอาการง่วงนอน
b. เส้นใยจากใบพืชทีแข็ง
C. ความคิดซึงไม่ถูกต้อง
d. สารซึงทำให้มีอาการตืนตัวและกระฉับกระเฉง
e. ไม่ทราบคำตอบ

118 impale: He nearly got impaled.
a. ถูกดำเนินคดีด้วยข้อหารุนแรง
b. ติดคุก
C. แทงด้วยของมีคม
d. มีส่วนร่วมในความขัดแย้ง
e. ไม่ทราบคำตอบ

119 coven: She is the leader of a coven.
a. นักร้องกลุ่มเล็กๆ
b. ธุรกิจซึงคนงานหรือผู้ปฏิบัติเบ็นเจ้าของกิจการ
C. สมาคมลับ
d. กลุ่มผู้หญิงผู้ปฏิบัติตามหลักศาสนาอย่าง เคร่ง ครัด
e. ไม่ทราบคำตอบ

120 trill: He practised the trill.
a. ส่วนเสริมในดนตรี
b. ชนิดของเครืองดนตรีประเภทสาย
C. วิธีการขว้างลูกบอล
d. การเต้น โดยใช้การหมุนตัวอย่างรวดเร็วบน ปลาย น้วเท้า
e. ไม่ทราบคำตอบ 


\section{Thirteenth 1000}

121 ubiquitous: Many weeds are ubiquitous.
a. กำจัดยาก
b. มีรากยาวและแข็งแรง
c. พบได้ในประเทศส่วนใหญ่
d. ตายในช่วงฤดูหนาว
e. ไม่ทราบคำตอบ

122 talon: Just look at those talons!
a. จุดสูงของภูเขา
b. กรงเล็บทีแหลมคม ของนกนักล่า
c. เสือคลุมทำจากโลหะหนักใช้เพือป้องกันอาวุธ
d. บุคคลซึงทำอะไรงีเง่าโดยไม่รู้ตัว
e. ไม่ทราบคำตอบ

123 rouble: He had a lot of roubles.
a. หินสีแดง ทีมีค่ามาก
b. ญาติห่างๆ
C. เงินตราของประเทศรัสเซีย
d. ความรู้สึกผิดชอบหรือความยากลำบากอืนๆที เกิดขึนในใจ
e. ไม่ทราบคำตอบ

124 jovial: He was very jovial.
a. มีสถานะตำในสังคม
b. ชอบวิจารณ์หรือจับผิดผู้อืน
C. เต็มไปด้วยความสนุกสนาน
d. เบ็นมิตร
e. ไม่ทราบคำตอบ

125 communiqué: I saw their

\section{communiqué.}

a. รายงานสำคัญ เกียวกับองค์กร

b. สวนซึงสมาชิกหลายคนในชุมชนเบ็นเจ้าของ

C. สึงพิมพ์ใช้สำหรับการโฆษณา

d. การประกาศของทางการ

e. ไม่ทราบคำตอบ
126 plankton: We saw a lot of plankton.
a. วัชพืชมีพิษซึงขยายพันธ์อย่างรวดเร็ว
b. พืชหรือสัตว์น้ำขนาดเล็กมาก
C. ต้นไม้ซึงให้เนือไม้แข็ง
d. ดินเหนียวสีเทาซึงเบ็นสาเหตุของดินถล่ม
e. ไม่ทราบคำตอบ

127 skylark: We watched a skylark.
a. การแสดงการบินผาดโผนของเครืองบิน
b. วัตถุทีมนุษย์สร้างขึน ซึงเคลือนที่อยู่รอบโลก
C. ผู้เล่นกลเพือสร้างความสนุกสนาน
d. นกขนาดเล็กซึงบินสูงขณะร้องเพลง
e. ไม่ทราบคำตอบ

128 beagle: He owns two beagles.
a. รถยนต์เคลือนทีเร็ว มีหลังคาพับได้
b. ปึนขนาดใหญ'ซึงใช้ยิงคนหลายคนได้อย่าง รวดเร็ว
C. หมาขนาดเล็ก มีหูยาว
d. บ้านซึงสร้างในสถานทีพักผ่อน
e. ไม่ทราบคำตอบ

129 atoll: The atoll was beautiful.
a. เกาะทีเกิดจากการก่อตัวของปะการังมีรูปร่าง เหมื อนวงแหวนโดยมีทะเลน้ำเค็มอยู่ตรงกลาง
b. งานศิลปะที่เกิดจากถักทอภาพด้วยเส้นด้าย
C. มงกุฏขนาดเล็กประดับด้วยอัญมณีมีค่า ซึงสตรีส วมใส่ในเวลากลางคืน
d. สถานที่ทีแม่น้าไหลผ่านช่วงที่แคบๆ ซึง เต็มไปด้ว ยก้อนหินขนาดใหญ
e. ไม่ทราบคำตอบ

130 didactic: The story is very didactic.
a. มีความพยายามอย่างมากที่จะให้ข้อคิด
b. ยากทีจะเชือ
C. เกียวข้องกับการกระทำทีน่าตืนเต้น
d. เขียนในลักษณะทีทำให้คนอ่านไม่แน่ใจ ว่าหมาย ความว่าอย่างไร
e. ไม่ทราบคำตอบ 


\section{Fourteenth 1000}

131 canonical: These are canonical examples.
a. ตัวอย่างทีแหกกฎระเบียบ
b. ตัวอย่างทีได้จากหนังสือทางศาสนาหรือคัมภีร์
C. ตัวอย่างซึงเบ็นทียอมรับกันอย่างกว้างขวาง
d. ตัวอย่างทีค้นพบเมือเร็วๆนี
e. ไม่ทราบคำตอบ

132 atop: He was atop the hill.
a. ด้านล่างของ
b. ด้านบนของ
C. ด้านข้างของ
d. ด้านทีอยู่ไกลของ
e. ไม่ทราบคำตอบ

133 marsupial: It is a marsupial.
a. สัตว์ซึงมีกีบเท้า
b. พืชซึงมีอายุยืน
C. พืชซึงมีดอกหันไปทางพระอาทิตย์
d. สัตว์มีกระเป๋าหน้าท้องสำหรับลูกอ่อน
e. ไม่ทราบคำตอบ

134 augur: It augured well.
a. สัญญาว่าจะเกิดสึงดีในอนาคต
b. เบ็นไปตามความคาดหวัง
C. มีสีสันซึงเข้ากับสีงอืน
d. ทำให้เกิดเสียงใสและไพเราะ
e. ไม่ทราบคำตอบ

135 bawdy: It was very bawdy.
a. คาดการณ์ไม่ได้, ไม่สามารถคาดการณ์ได้
b. น่าเพลิดเพลิน
C. เร่งรีบ
d. หยาบคาย
e. ไม่ทราบคำตอบ

136 gauche: He was gauche.
a. พูดมาก
b. ยืดหยุ่นได้
C. งุ่มง่าม
d. ตัดสินใจแน่วแน่
e. ไม่ทราบคำตอบ

137 thesaurus: She used a thesaurus.
a. พจนานุกรมประเภทหนึง
b. สารประกอบทางสารเคมี
C. วิธีการพูดแบบพิเศษ
d. การฉีดเข้าไปใต้ผิวหนัง
e. ไม่ทราบคำตอบ

138 erythrocyte: It is an erythrocyte.
a. ยาเพือลดความปวด
b. ส่วนทีเบ็นสีแดงของเลือด
C. โลหะสีขาวออกแดง
d. สมาชิกของครอบครัวปลาวาฬ
e. ไม่ทราบคำตอบ

139 cordillera: They were stopped by the cordillera.
a. กฎหมายพิเศษ
b. เรือติดอาวุธ
C. แนวเทือกเขา
d. โอรสคนโตของกษัตริย์
e. ไม่ทราบคำตอบ

140 limpid: He looked into her limpid eyes.
a. ชัดเจนหรือใส
b. น้าตาร่วง
C. สีนำตาลเข้ม
d. สวยงาม
e. ไม่ทราบคำตอบ 